УДК 330.341.1:331.5

\title{
INNOVATIVE APPROACHES TO THE FORMATION OF A LABOR MOTIVATION SYSTEM AT MICRO, MESO- AND MACRO LEVELS
}

\author{
Harnyk O. A.
}

\begin{abstract}
Анотація. Автором в процесі дослідження було проаналізовано трансформаційні зміни у системі мотивації праці на різних рівнях. Розроблено комплекс рекомендацій щодо формування ефективної системи мотивації здатної забезпечити стійкий соціально-економічний розвиток вітчизняної економіки на інноваційних засадах.
\end{abstract}

Ключові слова: система мотивації праці, соціально-економічний розвиток, інноваційні засади, інноваційні підходи, життєвий цикл, корпоративна культура, гнучкі форми зайнятості.

The problem's setting. Management activity is characterized by evolutionary development which leads to the transformation of the economic person into the social person. Systemic changes taking place in our society and economy encourage the introduction of new (innovative) conceptual approaches to motivating staff. Changes in the character and content of labor, caused by the production automation, intellectualization and spreading humanistic tendencies in all spheres of society's life, inevitably affect the emergence of new incentives, motives, values of a man and formation of a modern motivational system of enterprises.

The analyses of resent publications on the theme. Studying transformational changes in the labor motivation system at different levels, the scientific results are analyzed in the writings of D. P. Bohynia [1], A. V. Vasylyk [2], V. M. Honcharov [3], A. M. Kolot [4], D. A. Komisarenko [5], I. G. Mantsurov [6], G. V. Monastyrska [7], M. V. Semykina [8] and others. At the same time, from the scientific and practical point of view, the problem of the formation of an effective system of labor motivation under modern conditions of management requiring application of innovative scientific and methodological approaches to the formation of such system is not sufficiently researched.

The aim of the article. The main purpose of the research is to develop recommendations for the formation of an effective system of labor motivation capable of ensuring sustainable socio-economic development of the domestic economy on an innovative basis.

The main results and its grounding. The purpose of functioning labor motivation system is to create the necessary ideological basis for understanding new tasks during the formation of the enterprise's motivational system. The tasks that specify its purpose are: firstly, the theoretical and methodological provision of objectivity of the main conceptual provisions; secondly, activation of motivational processes in the enterprise; thirdly, creation of the necessary base for increasing the level of incentives for the personnel of the enterprise; fourthly, formation of internal staffing needs to work qualitatively and effectively.

Taking into account tasks, the content is formed, a motivational strategy and a program is developed specifying goals and objectives of the concept and strategy and reflecting the complex of management and socio-economic measures aimed at implementation of the motivational policy, as well as the mechanism for its implementation is developed.

A well-planned system of labor motivation can significantly increase the efficiency of personnel work, increase sales, improve the production process and customer service without much material costs and strengthen the market economy of the country. After all, when an employee performs his duties with 
complete dedication and his goals of self-development include the development of an enterprise in general, the coefficient of usefulness increases several times. As a rule, the lack of motivation is the first step towards a decline at the micro, meso- and macro- levels, since the disgruntled employee does not perform his duties qualitatively, behaves badly and distributes negative information about the company, as a result of which the company's reputation and prestige are lost.

Assessing the evolutionary way of development of social, economic, cultural, environmental and other processes taking place in the world, we can speak about main tendencies of the development of society which will influence directions of the formation of labor motivation system under the conditions of innovative changes in the economy and reflected in the generally accepted concept:

1) spreading globalization processes on the planetary scale which will lead to internationalization of production, exchange, distribution, consumption and, ultimately, the lifestyle (which will determine needs of a man, and, consequently, motives of its activity);

2) changing the management philosophy in connection with spreading humanitarian tendencies which will promote the development of social-oriented management, aimed not at an individual, but on the integrity (common mission, common goal and common interests);

3) spreading innovation in all segments of human life and, as a result, a partial return to the technical component, but on a qualitatively different basis. It is an integrated one which shows interconnection of technologies from different sectors that will influence processes of socialization and humanization of labor and will change the labor content;

4) informatization of all spheres of society, labor virtualization, changing approaches not only to labor content but also to its evaluation [8].

At the same time, it is necessary to understand that realities of the modern Ukrainian economy emphasize the attention of scientists and practitioners on the need for effective management of the enterprise. Personnel management representing a human factor for the development of production becomes of special significance.

As a result, new human resources management system gradually began to be formed. However, it should be admitted the fact that no matter what the beautiful ideas, the latest technologies and the fairest external conditions, but without forms and methods of material incentives for personnel, it is impossible to achieve high-performance work. One of these guidelines is the choice of priority directions of the formation of labor motivation system characterizing interests of all subjects of the labor market and improving this system, taking into account the stages of the "life cycle". This is shown schematically in Figure 1.

Directions of the development of labor motivation system corresponding to sector 1 (Figure 1) are achievement of the optimum point, the consensus of interests of employers, workers and society as a whole will be positioned in the modern economy first of all. This will provide an opportunity for the fastest effect and cost-effectiveness from the implementation. Employers are interested in applying these stimulating methods of work in this system; employees are interested in their application and use; public and nongovernmental organizations are interested in the support of implementation of motivation methods. It is worth noting that such segment is characterized by a combination of interests of all participants in the process of stimulation and motivation.

So, for example, such stimulating factor as increasing wages satisfies interests of all participants in the system of labor motivation. An employee receives larger material reward for the same amount of work which allows him to have higher level of purchasing power. The society receives a general increase in the subsistence minimum, an increase in the amount of social benefits and material assistance; state institutions receive an 
increase in capital inflows; employers and (costs of implementing the incentive factor in employees get significant amounts of profits "wage increases" are low).

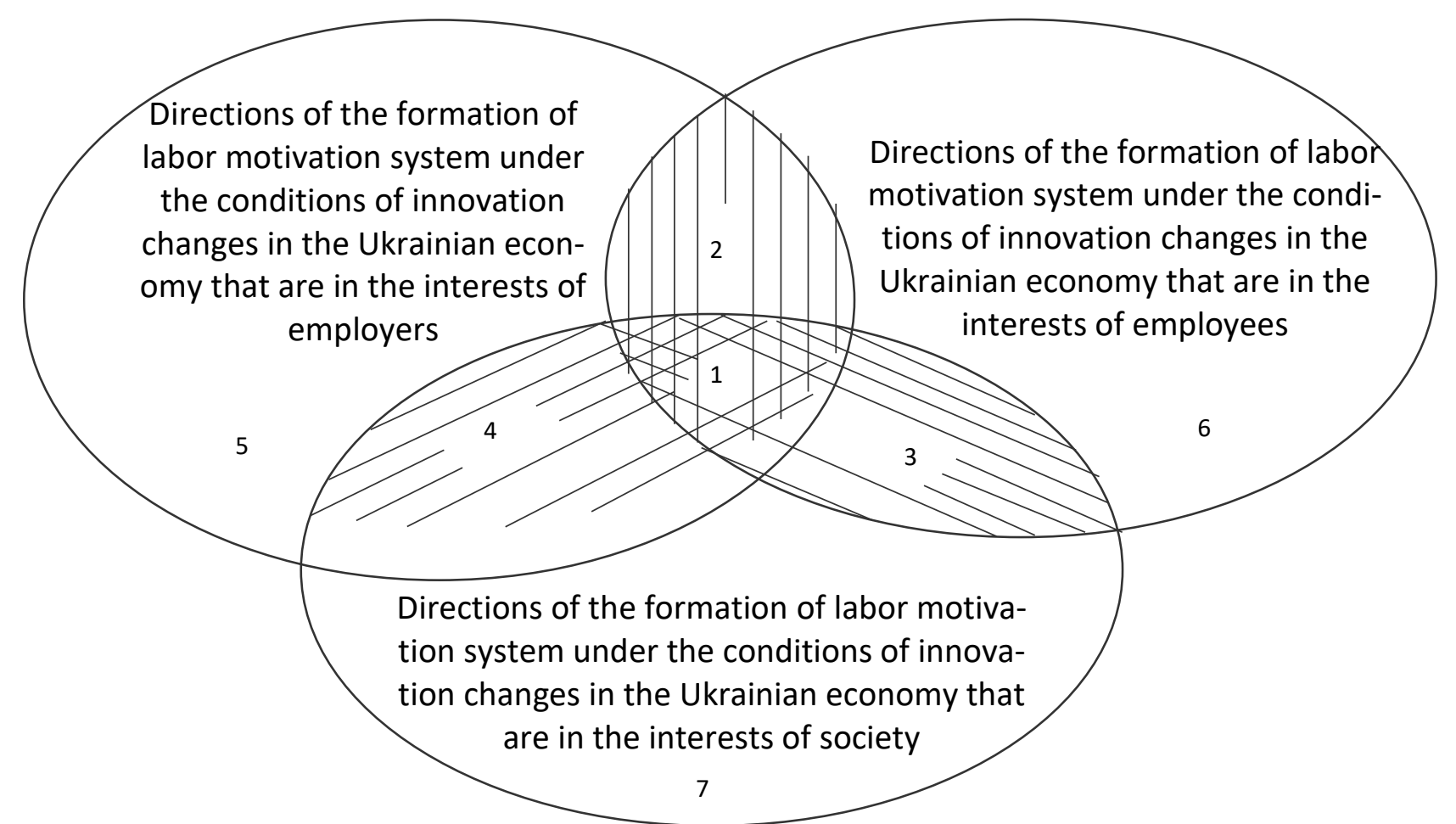

\section{Fig. 1. Model for coordinating interests of subjects of labor motivation system under the conditions of innovative development of the economy}

Source: [9].

Directions of formation and development that meet the sector of interests 2 are quickly and positively implemented in the enterprises. Employers are interested in implementing appropriate incentive methods, thus creating a significant human resource potential and systems for motivating labor at the micro, mesoand macro- levels. Employees form demand for labor. However, such motivating factor as "wage increases" is not a direct interest for both enterprises and government organizations. For this reason, they have the opportunity not to implement it, unless economic interests of enterprises and interests of state institutions are taken into account. Employers are not interested in directions of the formation of labor motivation system under the conditions of innovation in the Ukrainian economy, according to segment 3 , that is taking into account interests only of employees and society. For example, it is the conclusion of long-term employment contracts which will reduce the supply of skilled labor on the market that is not beneficial to employers. Also, employers cannot rely on loyalty and work efficiency for objective reasons (for example, permanent sick leave, maternity leave, childcare leave and so on). In such situations, employees or state institutions are required to motivate employers and this is only possible if their profits exceed costs of their incentives.

Employees are not interested in directions of the formation of labor motivation system, according to segment 4 that is taking into account interests only of employers and society. Therefore, implementation of certain incentives of this group requires support from local, regional or state self-government which will take place provided that costs of labor motivation are supplemented by additional profits. 
Directions of the development characterizing interests only of employers, employees or the state (region) separately, are unacceptable, since they are subjected to significant influence from other participants in this system. However, sometimes one of the participants may influence others.

Thus, it is necessary to choose priority directions of the formation of labor motivation system under the conditions of the innovative development of the Ukrainian economy which characterize interests of all subjects of the labor market to greater extent. This will enable to reduce extra costs to a minimum level, as well as hope for an increase in the life cycle of innovations. First of all, the ultimate goal of using the model of reconciliation of interests is achieving a high level of labor quality on the basis of creating a proper corporate culture, conducive to solving issues of increasing human capital. At the same time, size and quality of human capital become the main factors of sustainable development, that is, such development in which the total capital of society is preserved, including reproducible capital (equipment, buildings, etc.), natural capital (natural resources and quality of environment) and human capital.

Table 1

\section{Characteristics of labor motivation system at all stages of the life cycle of the enterprise}

\begin{tabular}{|c|c|c|c|}
\hline $\begin{array}{l}\text { Stages of } \\
\text { the life cycle }\end{array}$ & $\begin{array}{c}\text { The role of an } \\
\text { employee in la- } \\
\text { bor motivation } \\
\text { system }\end{array}$ & Methods of labor motivation & $\begin{array}{l}\text { Criteria (indicators) of the effective- } \\
\text { ness of labor motivation system man- } \\
\text { agement in the enterprise }\end{array}$ \\
\hline Birth & $\begin{array}{l}\text { Enthusiastic fol- } \\
\text { lower }\end{array}$ & $\begin{array}{l}\text { Application of motivational levers of influ- } \\
\text { ence on the use of attracted human resources }\end{array}$ & $\begin{array}{c}\text { Average number of staff; quantitative } \\
\text { and qualitative staffing; coefficient of } \\
\text { staff turnover; coefficient of use of the } \\
\text { working time fund }\end{array}$ \\
\hline \multirow[b]{2}{*}{$\begin{array}{l}\text { Growth } \\
\text { (childhood } \\
\text { and youth) }\end{array}$} & $\begin{array}{c}\text { Focused on } \\
\text { achievement }\end{array}$ & \multirow[b]{2}{*}{$\begin{array}{c}\text { Traditional methods of motivation: growth of } \\
\text { wages, bonuses, surcharges, allowances, bo- } \\
\text { nuses by results of work, increase of its } \\
\text { productivity }\end{array}$} & \multirow{2}{*}{$\begin{array}{c}\text { Labor productivity; } \\
\text { size of real and nominal wages; coeffi- } \\
\text { cient of staff turnover; share of certi- } \\
\text { fied jobs; coefficients of use of } \\
\text { innovations; degree of satisfaction with } \\
\text { labor; level of social tension and con- } \\
\text { flict }\end{array}$} \\
\hline & $\begin{array}{l}\text { Focused on de- } \\
\text { velopment }\end{array}$ & & \\
\hline \multirow[b]{2}{*}{$\begin{array}{l}\text { Maturity } \\
\text { (early ma- } \\
\text { turity, flow- } \\
\text { ering, full } \\
\text { maturity) }\end{array}$} & $\begin{array}{l}\text { Focused on im- } \\
\text { proving work }\end{array}$ & \multirow{2}{*}{$\begin{array}{l}\text { Motivation for the general result by means of } \\
\text { participation in profits, individualization of } \\
\text { wages by the level of education, qualification, } \\
\text { intellectualization and innovation of labor, ap- } \\
\text { plication of new forms of employment, provi- } \\
\text { sion of career and professional growth, } \\
\text { expansion of the system of social privileges }\end{array}$} & \multirow{2}{*}{$\begin{array}{c}\text { Labor productivity; } \\
\text { coefficient of personnel qualification; } \\
\text { share of workers involved in property; } \\
\text { number of rational proposals for one } \\
\text { worker }\end{array}$} \\
\hline & $\begin{array}{l}\text { Socially } \\
\text { responsible }\end{array}$ & & \\
\hline Renaissance & $\begin{array}{l}\text { Enthusiast-inno- } \\
\text { vator }\end{array}$ & $\begin{array}{l}\text { Labor motivation to increase competitiveness; } \\
\text { use of innovative methods; raising skills of } \\
\text { employees and their interest in implementing } \\
\text { modern knowledge in innovation activities; } \\
\text { formation of innovative corporate culture }\end{array}$ & $\begin{array}{l}\text { Labor productivity; } \\
\text { coefficient of personnel qualification; } \\
\text { share of employees involved in prop- } \\
\text { erty; share of introduction of the latest } \\
\text { technologies; number of scientific de- } \\
\text { velopments and production of science- } \\
\text { intensive products; share of use of in- } \\
\text { tellectual potential and creatively ac- } \\
\text { tive workers }\end{array}$ \\
\hline
\end{tabular}

Source: [9].

Improvement of labor motivation system must be carried out at all stages of the life cycle of the enterprise. Based on the levels of "life cycle" in Table 1, the system of interdependencies supplemented by us between labor motivation system and its "life cycle" is shown. Along with the main features of labor motivation system, characterizing each stage of the life cycle, problems and causes that cause a crisis situation in the 
enterprise are presented [5;9].

At the stages of "birth" and "growth" a particular emphasis should be placed on an employee, his personality and professional characteristics. At the stage of "maturity" methods of labor motivation are of particular importance in order to achieve certain performance indicators. Therefore, for this stage of the company's life cycle, the use of such methods as income participation, individualization of wages, application of new forms of employment, career and career development and expansion of the system of social benefits are characteristic.

The stage of "Renaissance" is characterized by the desire for reorientation, rejuvenation, restoration of the company's competitiveness. As a result, personal and professional characteristics of the individual as an innovator (ability to innovate, study, and retrain and initiativeness) and use of innovative methods of labor motivation, introduction of new structures of personnel management and formation of innovative corporate culture are given first place.

Thus, the economic efficiency of production depends on labor motivation system and the choice of the model of this system is determined by the stage of the enterprise's life cycle. It should be noted that each stage of the life cycle puts the company before specific problems. Such critical situations can be eliminated by introducing certain changes in the motivational system which should be implemented in the shortest possible time. Exiting the crisis requires the change in the concept of motivation and staff incentives.

Corporate culture plays an important role in labor motivation system and it is characterized by a set of rules, norms of behavior, internal values that are not subject to explanation but are the basis of it. The attitude of employees to their official duties is largely due to their personality, professional level of preparation and character. This formation of a corporate person takes place under the influence of the environment on the enterprise, firm or organization.

The relationship between corporate culture and labor motivation system is objectively determined by their general target orientation for the formation of labor behavior patterns that contribute to personal and organizational development. However, unified conceptual foundations have not yet been developed in the economic science to integrate principles of motivation theories and corporate culture into a logically interconnected, integrated system of scientific knowledge of principles and methods of managing labor behavior which ensure the maximum use of labor potential.

Improving its organization is one of directions for improving labor motivation. It contains goal setting, expansion of labor functions, labor enrichment, production rotation, application of flexible schedules and improvement of working conditions.

The main factor in the development of distance employment is the rapid development of information and communication technologies and formation of an information society. The service sector plays the dominant role in it.

The practice of a number of developed countries has shown that distance employment not only means the ability to work at home but also fosters more flexible employee approach to performing his functions, since he can optimize the use of working time. The use of nonstandard forms of employment modifies the system of labor relations and labor market functions, the role of trade unions, stimulates competition in the market, influences the nature of labor demand and supply, stimulates adaptation of companies to new forms of labor which serve as the basis for increasing their competitiveness, increases alternative for both consumers of labor, as well as workforce owners.

Flexible forms of employment are a phenomenon of the new labor market. They can be classified according to criteria and parameters and influence transformation of employment 
flexibility mechanisms as a way of changing employment parameters (volume and structure of demand and labor supply) under the influence of external and internal factors and interconnected. Thus, adapting the firm to external factors by changing the number of employees (numerical flexibility) and duration of the working day (time flexibility) leads to transformation of quantitative employment parameters. At the same time, changes in the organization of labor processes (functional flexibility) and in the system of workplaces (spatial flexibility) are its qualitative characteristics [1].

The time flexibility mechanism includes a flexible work schedule, overtime work, parttime work and leave on a voluntary basis and on the initiative of the administration. Main mechanisms of functional flexibility are transfer of workers to another place of work for production necessity and execution of works that are not duties of the employee. The mechanism of spatial flexibility is remote flexibility (employment outside of the main office during all or part of the working week).

Under the conditions of the financial and economic crisis in Ukraine, accompanied by a reduction in aggregate demand, enterprises most often used flexible forms of employment: involuntary part-time employment (partial unemployment); part-time employment patterns; non-standard organizational forms of employment: temporary work, secondary employment (part-time), "distance" employment or "freelance", "borrowed labor" (outsourcing, outstaffing, leasing of personnel); non-standard jobs: homework, call workers; flexible (nonstandard) working-time regimes that can be applied both for full time and part-time work.

The use of flexible employment has its advantages and disadvantages. The main advantages include:

- regulation of working time taking into account the economic situation in the enterprise;

- saving of expenses by increasing duration of the working day, flexible working hours of workers in the transition to flexible working hours;

- increase in labor productivity (the use of flexible forms of employment leads to its growth by $20 \%$ );

- quick and effective response to changes in supply and demand in the labor market;

- minimizing problems of retiring the company's employees by moving from full employment to its flexible forms;

- replenishment of the labor market by youth and its adaptation to new working conditions; increase (or saving in the reduction of production volumes) of the number of employed without increasing the number of jobs;

- there is an opportunity at the individual level to meet the needs of individual citizens in a combination of work with other social responsibilities.

Along with positive aspects of application of flexible forms of employment and working hours, it is worth noting some negative aspects. In particular, they include: difficulties in organizing work under conditions of multi-shift work; less adaptability of workers employed part-time in production teams; increased fatigue of workers in case of compressed working time regime; insufficient or absent social protection of workers, alienation of them from goals of the organization; resource-based approach to labor instead of humanistic approach aimed at developing labor potential and improving the quality of worker life. It should also be noted that the use of flexible forms of employment in the context of the innovative development can be an alternative to unemployment. Accordingly, it requires the development of rules of legal regulation of this area in accordance with general trends in the development of the European labor legislation.

Conclusions and further prospects of the research. The above makes it possible to conclude that under the conditions of the innovative development of the economy there is a reassessment of labor values. This requires finding new approaches to determining factors 
that influence the formation of labor motivation system and consequences of their formation. The following factors influence the formation of labor motivation system under the conditions of the innovative development: internal (content and significance of labor) and external ones (organizational-economic, social-psychological, intellectual and innovative). At the same time, one of the most important factors in the formation of labor motivation system is the effectiveness of innovation introduction. Innovative factors are determined by creation of conditions that maximize the number of scientific developments and implementation of achievements in the scientific and technological progress and develop the creative activity of employees.

\section{Список використаної літератури}

1. Богиня, Д. П. Інноваційна праця в умовах трансформації економіки / Д. П. Богиня // Вісник Донбаської держаної машинобудівної академії. - 2008. - № 2(12). - С. 40-43.

2. Василик, А. В. Сучасні підходи до мотивації інтелектуальної активності персоналу підприємства / А. В. Василик // Формування ринкової економіки : зб. наук. праць. - Спец. вип. : Соціально-трудові відносини: теорія і практика. - К. : КНЕУ, 2010. - Т. І. - С. 124-132.

3. Гончаров, В. М. Зарубіжний досвід стимулювання інноваційної активності на підприємстві : аспекти оплати праці / В. М. Гончаров, О. В. Додонов, С. В. Гончаров // Вісник Хмельницького національного університету. Серія «Економічні науки». - Хмельницький, 2008. - Вип. № 3. Т. 1. - С. 141-143.

4. Колот, А. М. Інноваційна праця та інтелектуальний капітал у системі факторів формування економіки знань / А. М. Колот // Глобальна економіка XXI століття: людський вимір : монографія / [Д. Г. Лук'яненко, А. М. Поручник, А. М. Колот, Я. М. Столярчук та ін.] ; за заг. ред. Д. Г. Лук'яненка, А. М. Поручника ; М-во освіти і науки України, ДВНЗ «Київ. нац. екон. ун-т ім. Вадима Гетьмана». - Київ : КНЕУ, 2008. - С. 93-104.

5. Комісаренко, Д. А. Принципові підходи до побудови моделі життєвого циклу підприємства малого бізнесу / Д. А. Комісаренко // Регіональні перспективи. - 2004. - № 3-5. С. 61-63.

6. Манцуров, І. Г. Збалансованість попиту та пропозиції на ринку кваліфікованої праці як фактор інноваційного розвитку економіки України : монографія / І. Г. Манцуров, 3. П. Бараник, С. С. Ващаєв, А. В. Яценко ; [за наук. ред. д-ра екон. наук, проф. І. Г. Манцурова]. - K. : KHEУ, 2008. - 381, [3] c.

7. Монастирська, Г. В. Багаторівневість системи мотивації українського працівника / Г. В. Монастирська // Вісник Хмельницького національного університету. - Хмельницький, 2011. - Вип. № 6. Т. 1. - С. 115-118.

8. Семикіна, М. В. Мотивація праці: нова парадигма в умовах конкурентного середовища / М. В. Семикіна // Чернігівський науковий часопис. Серія 1 «Економіка і управління». Чернігів, 2011.- Вип. № 2(2). - С. 118-126.

9. Ткаченко, О. А. Удосконалення системи мотивації праці в умовах інноваційного розвитку. / О. А. Ткаченко // Інноваційна модель розвитку: тенденції та перспективи економічної трансформації : колективна монографія / за ред. В. Д. Бесєдіна, А. С. Музиченка. - Умань : ФОП Жовтий О. О., 2014. - С. 220-226.

\section{Бібліографічний опис для циитування:}

Harnyk, O. A. Innovative approaches to the formation of a labor motivation system at micro, meso- and macro levels / O. A. Harnyk // Науковий журнал «Економічні горизонти». - 2017. - № 2(3). - C. 31-37. 